\title{
Exercise intensity, but not electrolyte reposition, alters plasmatic cortisol and glucose levels of horses submitted to 30 and $60 \mathrm{~km}$ distance endurance rides
}

\author{
A intensidade do esforço, mas não a reposição eletrolítica, altera as concentrações plasmáticas de cortisol \\ e glicose de eqüinos em provas de enduro de 30 e $60 \mathrm{~km}$
}

\author{
Antônio Raphael Teixeira-Neto ${ }^{\mathrm{I}}$ Guilherme de Camargo Ferraz ${ }^{\mathrm{I}}$ Flora Helena de Freitas D’Angelis ${ }^{\mathrm{I}}$ \\ José Corrêa de Lacerda-Neto ${ }^{\text {II }}$ Antonio de Queiroz-Neto ${ }^{{ }^{*}}$
}

\begin{abstract}
This study was aimed at comparing cortisol and glucose plasmatic levels in a group of trained horses submitted to 30 and $60 \mathrm{~km}$ endurance exercises, at the average speed of 10 and $15 \mathrm{~km} \mathrm{~h}^{-1}$, respectively. The horses were randomly divided in two groups, one treated, orally, with a hypertonic electrolyte paste before, during and after the tasks and the other used as control. Cortisol data revealed significant increase in the first moment when the intensity of the exercise was higher $(15 \mathrm{~km} / \mathrm{h})$ or with the prolongation of it (30km long), in the second moment to all groups. Glucose data remained constant during $30 \mathrm{~km}$ ride; however after $20 \mathrm{~km}$ distance, in $60 \mathrm{~km}$ ride, it revealed a significant increase in control group, returning to basal levels in the subsequent moment. Electrolyte replenishment has its importance in the maintenance of the hidroelectrolyte and acid-base status and, in this study, may have contributed to the homeostasis of glucose levels.
\end{abstract}

Key words: electrolytes, endurance, cortisol, glucose.

\section{RESUMO}

O presente estudo teve como objetivo comparar os níveis plasmáticos de glicose e cortisol de um grupo de eqüinos atletas submetidos ao esforço de longa duração (enduro eqüestre) em distâncias de 30 e $60 \mathrm{~km}$, com velocidades médias de 10 e $15 \mathrm{~km} \mathrm{~h}^{-1}$, respectivamente. Os animais foram aleatoriamente separados em dois grupos, sendo que a um deles foi administrada, por via oral, uma pasta eletrolítica hipertônica antes, durante e após as referidas provas. O outro grupo foi usado como controle. Os resultados das concentrações de cortisol revelaram um aumento significativo, no primeiro momento, em que a intensidade do esforço era maior $(15 \mathrm{~km} /$ h), ou com a continuação deste (30km de distância), no segundo momento, para todos os grupos. Os resultados referentes à concentração de glicose permaneceram constantes durante a prova de $30 \mathrm{~km}$; entretanto, nos primeiros $20 \mathrm{~km}$ da prova de $60 \mathrm{~km}$, tais resultados revelaram um aumento significativo no grupo controle, retornando a valores basais no momento subseqüente. A reposição eletrolítica tem a sua importância na manutenção do equilíbrio hidroeletrolítico e ácido básico $e$, no presente estudo, pode ter contribuído para a manutenção da concentração média de glicose plasmática.

Palavras chave: eletrólitos, enduro, eqüinos, cortisol, glicose.

\section{INTRODUCTION}

The endurance exercise is an equestrian sport modality of prolonged aerobic effort of variable intensity where a horse is submitted to a permanent work. Among the physiologic variables, the importance of body thermoregulation stands out, which is maintained, in the horse, mainly by sweat loss with organic fluid depletion.

The main task of the endocrine regulation system during exercise is the maintenance of serum glucose level. Cortisol can be considered the main glucocorticoid responsible for the stimuli to mobilize fatty acids from adipose tissue. In addition, it mobilizes tissue proteins, leaving the aminoacids available for hepatic gluconeogenesis. However, cortisol diminishes the cellular rate of glucose utilization. As exercise intensity increases, cortisol secretion also slopes upward, showing the interdependence between this hormone and glucemic regulation (POWERS, 2000).

IDepartamento de Morfologia e Fisiologia Animal, Faculdade de Ciências Agrárias e Veterinárias (FCAV), Universidade Estadual Paulista (UNESP), Campus de Jaboticabal. Via de acesso Prof. Paulo Donato Castellane s/n. 14870-900, Jaboticabal, SP, Brasil. Email: aqueiroz@fcav.unesp.br.*Autor para correspondência.

IDDepartamento de Clínica e Cirurgia Veterinária, FCAV, UNESP, Jaboticabal, SP, Brasil. 
Plasma glucose generally increases with all forms of exercise because of stimulation of hepatic glyconeogenesis. However, with prolonged exercise, glucose concentrations will decrease as a result of liver glycogen depletion (TRILK et al., 2002)

Maintenance of the hidroeletrolitic balance is fundamental for homeostasis in the equine organism. Considering body weight losses during a low intensity and long lasting effort, it can be estimated that a horse looses anywhere from 10 to 15 liters of sweat per hour, containing large electrolytes concentrations (ROSE et al., 1990). In humans, as a consequence of fluid and electrolyte depletion, a thermoregulatory failure as well as remarkable decreases in plasma glucose concentration contributing to performance loss and fatigue in endurance exercises (ARMSTRONG et al., 1985; CADE et al. ,1992; SAWKA, 1992). A recent study has shown electrolyte absorption in supplemented horses (TEIXEIRA-NETO et al., 2004).

The goal of this study is to search if an electrolyte reposition has any interference in plasma glucose and cortisol levels in a group of trained horses for endurance exercise, submitted or not (control group) to the reposition, before, during and after the effort, in experimental conditions simulating 30 and 60 kilometer endurance rides.

\section{MATERIALS AND METHODS}

A 30 and a 60 kilometer long distance endurance ride were simulated. In the first ride, the horses completed a 20 and a $10 \mathrm{~km}$ long distance ring, with an average speed of $10 \mathrm{~km} \mathrm{~h}^{-1}$. In the second ride (60km long) horses had to complete both rings (20 and $10 \mathrm{~km}$ ), but at an average speed of $15 \mathrm{~km} \mathrm{~h}^{-1}$, and an additional $30 \mathrm{~km}$ ring at $10 \mathrm{~km} \mathrm{~h}^{-1}$.

In the first endurance ride (30km), 15 trained horses (13 Arabian and 2 Mangalarga), with an average weight of 346 to $464 \mathrm{~kg}$ (8 geldings and 7 mares), were used.

In the second one (60km), 18 trained horses (15 Arabian and 3 Mangalarga), with an average weight of 340 to $440 \mathrm{~kg}$ (10 geldings and 8 mares) were used. They were ramdomly divided in two groups. The treated group, with 8 horses for each ride, which received the electrolyte paste throughout the task and the control group, with 7 and 10 horses for the first and second ride, respectively.

The horses were trained during a three month period to complete $30 \mathrm{~km}$ ride, and additional six months to $60 \mathrm{~km}$ endurance effort. This conditioning period consisted of riding the horses three to five times a week throughout the Campus trails at the Faculdade de Ciências Agrárias e Veterinárias (FCAV/UNESPJaboticabal).

In the morning of both rides horses were taken away from the field and prepared for the task. The beginning of the rides occurred at 7:00 a.m., and horses had to go through easy field trials, with water access at each $10 \mathrm{~km}$. While at the vet check gate, water and forage were offered ad libitum.

Clinical data and blood samples for laboratory tests were collected in four moments. Before the ride $\left(\mathrm{M}_{0}\right)$, during the first vet check at the end of the first ring ride $\left(\mathrm{M}_{1}\right)$, while in the second vet check at the arrival from the second ring ride $\left(\mathrm{M}_{2}\right)$; and $\mathrm{M}_{3}$, at the end of the additional third ring in the $60 \mathrm{~km}$ ride. All rings were concluded in the Veterinary Hospital. Upon the arrival from each ring, the horse was kept during 30 minutes at the vet check area until starting the next ring.

Oral electrolyte reposition was done with a hypertonic paste (specially manipulated for this experiment), made of $21 \mathrm{~g}$ of sodium chloride, $21 \mathrm{~g}$ of potassium chloride, $4 \mathrm{~g}$ of calcium chloride and $6.5 \mathrm{~g}$ of magnesium oxide, in excipient made up to $60 \mathrm{~g}$ and an artificial tuti-fruti flavor; which was given 1 hour before the start, at each $10 \mathrm{~km}$ of the ride and at the end of the ride.

The blood sample was obtained through jugular vein puncture with 40x12 needle withdrawing $15 \mathrm{~mL}$, in vaccutainer tubes with heparin and without any blood anticoagulant. The plasma cortisol dosage was done by radioimuneassay using the DPC (Diagnostic Products Corporation) kit. The cortisol intra assay was made to certify its quality, which showed a variation coefficient of $9.19 \%$. The glucose plasma concentration resolution was done by i-STAT portable blood analyzer, with EC8 ${ }^{+}$card, with heparinized blood.

Each horse was submitted to a complete clinical exam during every vet check with the purpose of eliminating any horse that might show any metabolic disorder, indicated mainly by a heart rate increase, by lameness or soreness that could impair horse performance during the ride. The evaluated physiologic variables were: heart rate, respiratory rate, mucous membranes color, capillary reperfusion time, body temperature and lameness evidence. The body weight was also evaluated at each vet- check.

For statistical analysis the PROC GLM of the SAS v. 6.12 was used. The Tukey test $(\mathrm{P}<0.05)$ was used to compare the means. 


\section{RESULTS AND DISCUSSION}

In the $30 \mathrm{~km}$ ride no clinical alteration that could have eliminated any horse until the end of the ride was observed. However, in the $60 \mathrm{~km}$ ride, one horse of each experimental group was eliminated due to lameness, at the end of the first ring $\left(\mathrm{M}_{1}\right)$. In the second ring, $\left(M_{2}\right)$ three horses of the control group and one of the treated group were eliminated by heart rate increase (>64 beats minute ${ }^{-1}$ ) and, in the last ring of this ride, two more horses of the control group were eliminated by the same reason.

The blood cortisol concentration varies throughout the day, and in accordance to the activity intensity, e.g. an intense exercise increases the blood cortisol level, as shown by WONG et al. (1992). In the $30 \mathrm{~km}$ ride (Table 1 ), of the present study, this only was significant in $\mathrm{M}_{2}$. Otherwise, in the $60 \mathrm{~km}$ ride this increase was observed earlier in $M_{1}$, showing a

Table 1 - Mean value \pm standard error of related variables of horses, at different moments $\left(\mathrm{M}_{0}, \mathrm{M}_{1}, \mathrm{M}_{2}\right.$ and $\left.\mathrm{M}_{3}\right)$ of endurance rides at different speed $\left(\mathrm{V}_{10}=10 \mathrm{~km} \mathrm{~h}^{-1}\right.$ e $\mathrm{V}_{15}=15 \mathrm{~km} \mathrm{~h}^{-1}$ ), submitted (treated group $=\mathrm{T}$ ) or not (control group $=\mathrm{C}$ ) to electrolyte reposition.

\begin{tabular}{|c|c|c|c|c|}
\hline \multirow[b]{2}{*}{ Moment } & \multirow[b]{2}{*}{ Group } & \multirow[b]{2}{*}{$\mathrm{n}$} & \multicolumn{2}{|c|}{ Variables } \\
\hline & & & Cortisol $\mu \mathrm{g} \mathrm{dL^{-1 }}$ & Glucose mg dL ${ }^{-1}$ \\
\hline \multirow{4}{*}{$\mathbf{M}_{0}$ (start) } & $\mathrm{C}_{\mathrm{V} 10}$ & 7 & $4.5 \pm 0.4 \mathrm{~A}$ & $93.4 \pm 2.1 \mathrm{~A}$ \\
\hline & $\mathrm{T}_{\mathrm{V} 10}$ & 8 & $4.4 \pm 0.2 \mathrm{~A}$ & $92.7 \pm 1.9 \mathrm{~A}$ \\
\hline & $\mathrm{C}_{\mathrm{V} 15}$ & 10 & $6.1 \pm 0.6 \mathrm{a}$ & $93.5 \pm 1.4 \mathrm{a}$ \\
\hline & $\mathrm{T}_{\mathrm{V} 15}$ & 8 & $6.4 \pm 0.5 \mathrm{a}$ & $95.6 \pm 2.3 \mathrm{a}$ \\
\hline \multirow{4}{*}{$\begin{array}{l}M_{1} \\
(20 \mathrm{~km})\end{array}$} & $\mathrm{C}_{\mathrm{V} 10}$ & 7 & $5.4 \pm 0.5 \mathrm{AB}$ & $94.3 \pm 1.5 \mathrm{~A}$ \\
\hline & $\mathrm{T}_{\mathrm{V} 10}$ & 8 & $6.1 \pm 0.5 \mathrm{AB}$ & $99.7 \pm 5.7 \mathrm{~A}$ \\
\hline & $\mathrm{C}_{\mathrm{V} 15}$ & 9 & $14.2 \pm 1.5 \mathrm{~b}$ & $137.8 \pm 10.4$ \#b \\
\hline & $\mathrm{T}_{\mathrm{V} 15}$ & 7 & $12.5 \pm 0.6 \mathrm{~b}$ & $113.6 \pm 4.6 * \mathrm{a}$ \\
\hline \multirow{4}{*}{$\begin{array}{l}\mathrm{M}_{2} \\
(30 \mathrm{~km})\end{array}$} & $\mathrm{C}_{\mathrm{V} 10}$ & 7 & $6.4 \pm 0.5 \mathrm{~B}$ & $104.0 \pm 5.9 \mathrm{~A}$ \\
\hline & $\mathrm{T}_{\mathrm{V} 10}$ & 8 & $7.9 \pm 0.4 \mathrm{~B}$ & $114.9 \pm 10.6 \mathrm{~A}$ \\
\hline & $\mathrm{C}_{\mathrm{V} 15}$ & 6 & $13.0 \pm 1.6$ \#b & $123.8 \pm 9.1 \mathrm{ab}$ \\
\hline & $\mathrm{T}_{\mathrm{V} 15}$ & 6 & $14.1 \pm 1.4 \mathrm{~b}$ & $108.0 \pm 5.7 \mathrm{a}$ \\
\hline \multirow{2}{*}{$\begin{array}{l}\mathrm{M}_{3} \\
(60 \mathrm{~km})\end{array}$} & $\mathrm{C}_{\mathrm{V} 15}$ & 4 & $16.94 \pm 2.7 \mathrm{~b}$ & $107.0 \pm 9.0 \mathrm{ab}$ \\
\hline & $\mathrm{T}_{\mathrm{V} 15}$ & 6 & $16.40 \pm 1.7 \mathrm{~b}$ & $118.0 \pm 9.8 \mathrm{a}$ \\
\hline
\end{tabular}

* indicates statistically different mean $(\mathrm{P}<0.05)$ when compared to the control group of same speed and moment

\# indicates statistically different mean $(\mathrm{P}<0.05)$ when compared to the controls $\left(\mathrm{C}_{V 10}\right.$ and $\left.\mathrm{C}_{V 15}\right)$ at same moment.

Different letters indicate statistically different means $(\mathrm{P}<0.05)$ when compared to means of the same group in different moments. Capital letters are related to $\mathrm{V}_{10}$ and lower case letters are related to $\mathrm{V}_{15}$. significant difference in relation to $M_{0}$ for the control and treated groups, as well as for the control group of the $30 \mathrm{~km}$ ride, at $M_{1}$ and $M_{2}$. This reflects the effect of different effort intensity between the rides and supports several studies which showed that higher blood cortisol levels usually occur after maximal exercises (SNOW \& MACKENZIE, 1977; DYBDAL et al., 1980). The treated group in the $60 \mathrm{~km}$ ride presented a significant increase of cortisol concentration in $M_{1}, M_{2}$ and $M_{3}$. These results are in accordance with the study of POWERS (2000), that pointed out that under low intensity exercises, cortisol has a higher elimination rate than its production by the adrenal glands. When an increase in effort intensity occurs, a larger hormonal secretion can be evident.

Cortisol values in horses right after show jumping, cross country, trotting, galloping and endurance rides were compared by LINDEN et al. (1991), who showed that plasma cortisol levels after these exercises were similar, except for endurance rides, where plasma cortisol level was about 30 percent higher than in any of the other athletic activities. According to TABATA et al. (1991), cortisol production increases as the plasma glucose concentration decreases, stimulating the lipolisis and gluconeogenesis.

After long lasting exercises or endurance ride competitions, a decrease in the plasma glucose concentration has been most often observed (LUCKE \& HALL, 1980). Nevertheless, the concentration behavior over time and during an exercise must be considered.

The plasma glucose concentration was kept within the normal reference levels in $30 \mathrm{~km}$ ride of this study (Table 1). However, it was observed a significant increase in its concentration in the control group, at the end of the first $20 \mathrm{~km}$ ring $\left(M_{1}\right)$ of the $60 \mathrm{~km}$ ride. Hyperglycemia may be found during exercise depending on training status and intensity as well as duration of exercise (COOGAN, 1991; GREEN et al., 1995). SNOWet al., (1992), described that the extent of the increase in plasma glucose concentration is probably related to the degree of sympathetic activity, which is related to the intensity of exercise. On the other hand, HYYPPA et al., (1996), affirmed that the administration of an isotonic electrolyte rehydration solution administration after exercise helps to overcome dehydration better than water alone. These studies can explain the increase in glucose levels in that moment, for the control group. Nevertheless, this increase did not occur in the treated group revealing a point that has to be investigated in future studies to elucidate this fact. 


\section{CONCLUSIONS}

The intensity and the duration of exercise promote an increase in cortisol concentration and can alter glucose levels. Even though, cortisol interpretation should be done with caution because it can suffer interference from other factors not related to physical efforts and even in initial phases of endurance exercise hyperglycemia can be observed.

\section{ANIMAL WELFARE APPROVAL}

The present study is in accordance with Ethical Principles of Animal Experimentation, adopted by the Brazilian College of Experimentation (COBEA) and was approved by Ethical and Animal Welfare Commission (CEBEA), of Faculdade de Ciências Agrárias e Veterinárias (FCAV/UNESP-Jaboticabal), Jaboticabal, SP, Brazil.

\section{REFERENCES}

ARMSTRONG, L. et al. Influence of diuretic-induced dehydration on competitive running performance. Med Sci Sports Exercises, v.17, p.456-461, 1985.

CADE, R. et al. Marathon running: physiological and chemical changes accompanying late-race functional deterioration. Eur J Appl Physiol, v.65, p.485-491, 1992.

COOGAN, A.R. Plasma glucose metabolism during exercise in humans. Sports Medicine, v.11, p.102-104, 1991

DYBDAL, N.O. et al. Alterations in plasma corticosteroids, insulin and selected metabolites in horses used in endurance rides. Equine Vet J, v.12, p.137-140, 1980.

GREEN, H.J. et al. Adaptions in muscle metabolism to prolonged voluntary exercise and training. Appl Physiol, v.78, p.138145, 1995

HYYPPA, S. et al. Restoration of water and electrolyte balance in horses after repeated exercise in hot and humid conditions. Equine Vet J, v.22, p.108-112, 1996.
LINDEN, A. et al. Effect of different types of exercise, transportation and ACTH administration on plasma cortisol concentration on sport horses. In: Equine exercise physiology 3. Davis: ICEEP, 1991. p.391-396,.

LUCKE, J.N.; HALL, G.N. Further studies on the metabolic effects of long distance riding: Golden Horseshoe Ride 1979, Equine Vet J, v.12, p.189-192, 1980.

POWERS, S.K. Fisiologia do exercício teoria e aplicação ao condicionamento e ao desempenho. São Paulo: Manole, 2000. 527p.

ROSE, R.J. et al. Clinical exercise testing in the normal Thoroughbred racehorse. Aust Vet J, v.67, p.345-348, 1990.

SAWKA, M.N. Physiologic consequences of hypohydration: exercise performance and thermoregulation. Med Sci Sports Exercise, v.24, p.657-670, 1992.

SNOW, D.H. et al. Effects of high-intensity exercise on plasma catecholamines in the thoroughbred horse. Equine Vet $\mathbf{J}$, v.24, p.462-467, 1992

SNOW, D.H.; MACKENZIE, G. Effect of training on some metabolic changes associated with submaximal endurance exercise in the horse. Equine Vet J, v.9, p.226-230, 1977

TABATA, I. et al. Effect of low blood glucose on plasma CRF, ACTH and cortisol during prolonged physical exercise. J Appl Physiol, v.71, p.1807-1812, 1991.

TEIXEIRA-NETO, A.R. et al. Electrolyte reposition on physiologic variables of horses submitted to 30 and $60 \mathrm{~km}$ endurance rides. Ciência Rural, v.34, p.1505-1511, 2004.

TRILK, J.L. et al. A lactate-guided conditioning programme to improve endurance performance. Equine exercise physiology 6. Equine Vet J, v.34, p.122-125, 2002

WONG, C.W. et al. Effects of exercise stress on various imune functions in horses. Am J Vet Resp, v.53, p.1414-1417, 1992. 